\title{
ANGOLA'S 2017 ELECTIONS AND THE START OF A POST-DOS SANTOS ERA
}

\section{Zefanias Matsimbe and Nelson Domingos}

Zefanias Matsimbe is a lecturer in the Department of Political Science and Public Administration, Eduardo Mondlane University, Maputo, Mozambique and elections consultant in the EISA Mozambique Office

Nelson Domingos António is a lecturer in the Department of Political Science, University Agostinho Neto, Luanda, Angola and a member of the Angolan Association of Political Science (AACP)

\begin{abstract}
For the first time in the history of its multiparty democracy, Angola held general elections in August 2017 without President José Eduardo dos Santos on the ballot paper. In 2016 dos Santos decided not to run again for the presidency but he remained the party chair. Instead, João Manuel Gonçalves Lourenço was nominated to replace dos Santos as the MPLA candidate. The departure of dos Santos raised expectations that there would be political change in the country. However, this did not happen because the MPLA won a qualified majority in the National Assembly despite their decreased support compared to the results of the 2012 general elections. Though the 2017 elections were considered to have been well prepared and executed, the outcome was challenged by the opposition on the grounds of irregularities in voter registration, the accreditation of party agents, and problems in both counting and announcing the results. The change of leader raised a number of questions regarding the implications of a double centre of power in the MPLA and presidency. How João Lourenço will manage the question of the factions created by his rise to power is a matter of concern, together with whether he will be able to end the hegemony and economic power of dos Santos and his allies. He will also have to deal with the ongoing economic crisis and boost declining public trust in the MPLA. By addressing some of these issues this article provides an important contribution to understanding the electoral processes in Angola.
\end{abstract}

Keywords: Angola, MPLA, UNITA, José Eduardo dos Santos, elections, João Lourenço 


\section{INTRODUCTION}

Angola's long civil war ended in 2002. Fifteen years later, on 23 August 2017, they held their third general elections to elect the president, vice-president and 220 members of the National Assembly, as determined by the revised 2010 Constitution. The elections were contested by six political parties and one coalition, namely the Popular Movement for the Liberation of Angola (MPLA), National Union for the Total Independence of Angola (UNITA), National Front for the Liberation of Angola (FNLA), Social Renewal Party (PRS), National Patriotic Alliance (APN) and the Broad Convergence for the Salvation of Angola - Electoral Coalition (CASA-CE). This was fewer than in the previous general elections of 2012 in which nine parties participated. The election was also marked by a controversial decrease in the total number of registered voters which were $4.5 \%$ less than those registered in 2012.

The 2017 elections represent a significant landmark for Angola, most importantly because for the first time since they had opted for multiparty democracy in 1991, the ruling MPLA fielded a new presidential candidate, João Lourenço. This followed the resolve by José Eduardo dos Santos in December 2016 not to run again for the presidency. Dos Santos decided to end his 38 years as head of state but chose to remain in the party leadership, a decision not welcomed by party members. This decision by dos Santos highlighted the different ideas within the MPLA about the presidential succession.

This change of leadership within the MPLA ended up influencing the dynamics of the entire electoral process. Firstly, opposition parties assumed that the time had come for political change in the country since the removal of dos Santos, who had been the major obstacle to change. As a result, they increased their pressure on the ruling MPLA as polling day approached, with the aim of ending 38 years of damaging MPLA governance. Civil society organisations also stepped up their mobilisation initiatives for political change and a better redistribution of wealth.

Secondly, the retirement of dos Santos also offered some hope for political change and an improvement in the living conditions of the vast majority of economically and politically excluded citizenry. Voters who had previously not valued their participation in electoral processes began to reckon that this time their vote would count towards ending MPLA hegemony. The double pressure of opposition and society added to the impact of the financial crisis which had been triggered by the fall of oil prices, Angola's most important commodity. The consequent crisis of financial liquidity weakened the credibility of MPLA, particularly in urban areas.

The election results show that MPLA was able to overcome this political pressure by securing a qualified majority in the National Assembly, though it 
lost significant support compared to the previous elections in 2012. These results disappointed many who had expected different election outcomes and spelled the end of their dream of change.

Another significant aspect of the 2017 elections is that compared to previous elections in the dos Santos era, the general sentiment was that these elections were conducted in a relatively relaxed environment with more liberty, tolerance, freedom and political discourse. This is confirmed by the civil liberties index in V-Dem that jumped from 1.83 in 2016 to 2.0 in 2017 (v.dem 2018). Electoral observer missions also gave positive reports on the quality of these elections.

The electorate appeared to be more politically aware than in the past and participated in all phases of the electoral process. Nonetheless, several incidents of the misuse of state resources by the ruling MPLA were reported together with misconduct by the National Electoral Commission (CNE). The polling itself was highly competitive, leading to the widespread perception that MPLA was going to lose power through the ballot.

Many questions remain unanswered almost a year after the elections: these include concern as to how the co-existence of two commands will be managed while dos Santos continues to chair the MPLA; how Lourenço will manage the factions created by his rise to power; and how the new president will deal with the issue of the hegemony and economic might of dos Santos and his immediate supporters and allies. This article looks at some of these issues and thus contributes to an understanding of electoral processes in Africa, where they are less studied than in the more established democracies of Europe and America. The article offers an empirical analysis rather than a theoretical debate on elections. Where necessary the authors refer to various indexes to measure some of the components such as integrity and civil liberty.

Articles on elections tend to focus on the events of polling day and the immediate administration of elections. In this article we follow the electoral cycle framework which considers elections not as an event, but as a process with interconnected and interdependent phases. We focus on many other elements such as the legal framework, voter registration and register management, electoral campaigning, and polling and results management; aspects that are likely to affect the outcome of the electoral process and determine the integrity of the election.

Following this introduction, we provide the historical, socio-political and legal background and conclude with some uncertainties about the impact of leadership changes on Angola's future.

\section{BACKGROUND}

Formerly a Portuguese colony, Angola gained independence in 1975 under the leadership of the MPLA and Agostinho Neto. The euphoria of independence 
was soon eroded by periods of civil wars that ended only in 2002 with the death of UNITA leader Jonas Savimbi. The MPLA has had only two leaders since independence, Agostinho Neto (1975-1979) and José Eduardo dos Santos (from 1979).

Seen as a country still struggling with its violent past, Angola is also known for its political stability since the end of the civil war, with only a small degree of political disruption in the oil-rich region of Cabinda, an enclave claiming autonomy. The Front for the Liberation of the Enclave of Cabinda - Armed forces of Cabinda (FLEC-FAC), an armed movement fighting for the autonomy of Cabinda, had even threatened to boycott the August 2017 elections, calling it a 'foreign election' and claiming that Cabinda is a separate country from Angola. Sporadic instability has also been registered in the diamond-rich regions of Lunda Norte and Lunda Sul, two provinces that feel excluded from the redistribution of the revenue accruing from diamond exploitation.

Angola is a country rich in natural resources, the second largest producer of oil and third-largest producer of diamonds in Africa. The country has about 25 million inhabitants, $60 \%$ of whom are young. However, it continues to face the challenge of reversing this wealth to benefit the people, two-thirds of whom live on less than two American dollars a day. In 2017 the Human Development Index placed Angola in the group of countries with a low development index of 0.533 , and the country is known for the vast social discrepancies between its haves and have nots.

Following the end of the civil war in 2002, Angola became one of the fastest growing economies in the world. Its economy was stimulated by a substantial increase in oil production and the exponential increase of prices from 20 to 147 American dollars per barrel between 2002 and 2008, making it the third largest economy in sub-Saharan Africa (Pearce et al. 2018).

Although it was formally known as a multiparty democracy Angola did not develop from being an authoritarian regime to a democratic regime as was generally expected (Blaauw 2014). The country continued to experience the political repression of dissidents, social and pro-democracy activists, human rights abuses, restrictions on the freedom of expression and assembly, together with corruption and abuse by the security forces (Freedom House 2018). This is the opposite of Dahl's definition of democracy, which is that a democratic state is substantially popular and liberalised, strongly inclusive and open to public contestation (1997, pp. 25-26); has rulers who are elected in free, fair and periodic elections in a society which has guaranteed and effective freedom of expression, independent media (that is, not controlled by the government), autonomy of association and even citizenship (Dahl 1998, pp. 85-86). 
António (2015, p. 226) sees Angola as an example of what O`Donnell and Schmitter (1986) called liberalised authoritarianism, in that there is a persistence of manifestly authoritarian practices despite the existence of some democratic structures. The government tolerates a limited space for individual and collective action only in order to identify those who do not support its governance. They can thus restrict access to certain state benefits and persecute in other ways, and elections are bedevilled by suspicions about fairness and freeness.

In the reign of dos Santos Angola was known as a country with serious human rights abuses, extreme nepotism and an extensive network of patronage. It was a dictatorial regime characterised by corruption and the persecution of critics of the regime. Civil liberties remained oppressed as independent media continue to be subjected to legal and physical harassment. Anti-government protests began in 2011, expanded in 2013 and continued in 2014; they were violently dispersed and demonstrators intimidated, physically assaulted, arrested and beaten, with some still missing.

The MPLA established a clientelist network that allowed members of the MPLA and security forces to deplete state resources, especially in the extractive (mineral) sector, while ensuring the political longevity of dos Santos's leadership. State institutions were weakened by the high level of politicisation and the personalisation of state institutions around dos Santos, and by the nepotism and control of state administrative machinery by security forces. Even when he was on his way out, dos Santos placed his allies in key positions in order to diminish possible reform (Roque 2017).

Transparency International places Angola among the most corrupt countries in the world, ranking it at 167 out of 180 states analysed in 2017. Corruption scandals involved highly placed individuals in the party, notably the then Vice President Manuel Vicente, Generals Hélder Manuel Vieira Dias Júnior 'Kopelipa' and Leopoldino Fragoso do Nascimento 'Dino', together with President dos Santos and his family.

Government malfeasance has resulted in widespread discontent among the general public. The dissatisfaction is so high that it is even depicted in a survey sponsored by the Angolan Presidency and attributed to a Brazilian research and consulting company (Sensus) covering the country's 18 provinces (ClubK 2017a,14 August). Dissatisfaction is more visible in urban areas, including Luanda, a province normally seen as a natural supporter of MPLA, and where election results indicate that MPLA has suffered setbacks.

Quoting Mueller, Mathenjwa (2017, p. 182) considers that a country takes a positive step towards democratisation when it entrenches democracy in its constitution which must in turn be the citizens' choice. Furthermore, such a 
constitution must be a mandatory declaration that democracy will prevail and will be realised; these are the criteria for a constitutional democracy. Angola has made significant progress since the revision of the Constitution in 2010 followed by the revision of a number of other laws concerning democracy. The opposition has, however, called for further revisions as not all the legal provisions are fully consensual.

One of the innovations of the revised Constitution is the concentration of power in the person of the president and the replacement of the prime minister by the vice president. The revised Constitution also establishes the use of a single vote for the president of the Republic (first in the top-ranking list), the vice president (second in the top-ranking list), and members of the National Assembly. The ballot paper displays the photograph of the candidate next to the party symbol but provides only a single space to mark the choice. This means that those who choose party A automatically choose that party's candidate and vice versa. The system has been criticised as it does not allow alternative choices. The National Assembly consists of 220 Members of Parliament (MPs), 130 of whom are elected through the national constituency and the remaining 90 in the provincial constituencies, with five MPs for each of the 18 provinces. The election of MPs is based on the proportional system.

Another important change is that the executive ceases to have a direct role in the appointment of members of the $\mathrm{CNE}$, a role that falls to the parliament and is based on the proportionality of the seats. However, the fact that the MPLA holds the parliamentary majority ensures that it continues to dominate this body with 8 out of 11 commissioners. Furthermore, the Constitution stipulates that the CNE must be chaired by a judge; the fact that the judges are appointed by the president of the republic also ensures that the MPLA influences the appointment of the chair of this body. It is the same presidential prerogative that favours the MPLA in the appointment of judges to the Constitutional Court, the body invested with constitutional powers to arbitrate electoral processes in the country. Therefore, the independence of the $\mathrm{CNE}$ and the Constitutional Court are still disputed in the country and hinder public confidence in the electoral process, and it is known that 'the organization of electoral administration is the third main institutional "levelling" device that can be expected to be associated with public confidence in the electoral process' (Grömping \& Coma 2015, p. 22).

There have been significant changes in other relevant laws for the management of electoral processes, most importantly the Organic Law on Electoral Processes (2010), General Elections Law (2011), Election Observation Law (2012), Law on Political Parties Financing (2012), and the Law on the Establishment and Functions of the National Election Commission (2012). The electoral law has been highly contested by opposition parties. 


\section{TOWARDS POLLING DAY}

In December 2016 dos Santos announced his surprising decision not to run for the 2017 elections on the MPLA ticket. At the time rumours circulated that the deterioration of his health was the main reason for ending his 38 consecutive years in charge of MPLA and of Angola. In reality, the decision of dos Santos to resign from the presidency of Angola seems to emanate from an analysis of costs and benefits in relation to his continuation or abdication. The international pressure for his resignation included imposing on his government restrictions such as freezing the bank accounts of his family and members of the government and placing the country on a black list in order not to have access to the dollar. These seem to have contributed to his resignation. Other factors included the economic and financial crisis, dos Santos's loss of personal popularity, and internal protests calling for his abdication. Given this scenario, his resignation seemed to offer a cost-effective alternative compared to his continuing as Angolan president.

The announcement of dos Santos's resignation created some concern about possible political instability in the country and an internal struggle for succession within the MPLA. But the main fear was that dos Santos would implement a long-suspected intention of appointing one of his sons, Filomeno dos Santos, to replace him as a way of protecting the dos Santos family control of the economy.

The crisis of leadership succession was successfully managed with the appointment of Lourenço, former secretary-general of the party and a man with a military background (a former minister of defence) as MPLA candidate. Lourenço was not the first choice of dos Santos but was a compromise candidate and the only person agreed to by both dos Santos and other segments of the party.

The 2017 elections took place in a social and economic context quite different from previous elections that had given such a resounding victory to MPLA. Firstly, since 2013 Angola had been plunged into an economic crisis caused by the decline of oil-export earnings amid a global price decrease and an increase in general imports. This had negatively affected the economy, with consequences such as the scarcity of foreign exchange and a significant increase in inflation. Secondly, there was a high level of population discontent due to the poor supply of goods and services, exclusions and skewed patterns of wealth distribution. These resulted in a wide gap between a mostly urban bourgeoisie consisting of those close to the presidency and the majority living in extreme poverty (Pearce et al. 2018). Other negative factors included perceptions of high levels of corruption and nepotism by MPLA elite, and weak accountability of the country's leaders. These led to a drop in the levels of MPLA popularity with multiple protests at national level, especially in large urban centres.

The crisis affected the legitimacy of the MPLA as it gave the opposition the opportunity to accuse the ruling party of mismanaging public funds, which had 
resulted in the current crisis. The departure of dos Santos also triggered civil society organisation demands for a better distribution of the national wealth, and the demand that dos Santos relinquish power. This social mobilisation was stronger in urban areas (Pearce et al., 2018). The arrival of a new candidate other than dos Santos also revealed internal squabbles between the members of MPLA and factional differences around dos Santos and Lourenço.

A dominant sentiment in Angolan society ahead of the 2017 elections was that unlike previous elections, these would no longer be by plebiscite so there would be no direct vote for the MPLA candidate. The political opposition claimed that the time for political change had come, that neither a massive fraud nor use of incumbency and state resources would alter the results and prevent political change. They also called for MPLA to accept the election outcomes and willingly accept the role of opposition. The 2017 elections also happened at a time of heightening civic mobilisation by the new generation of citizens who were better educated and better informed. This was particularly true of youth in urban areas who were removed from the MPLA's historic reach, a factor that disadvantaged the MPLA.

The announcement of dos Santos's resignation brought contestant voices within MPLA into the open. These were critical of the economic power of the presidential family who were widely perceived to have accumulated wealth by improper acts. Speaking from prison, one of Angola's most respected generals publicly threatened Isabel dos Santos, a daughter of the former president, and for the first time openly accused her father of being corrupt (Africa-confidential 25 August 2017).

Despite the widely-held perception that this election had been better prepared than previous elections, a number of challenges were also reported. UNITA called for popular demonstrations in all provincial capitals to protest against what it called 'MPLA fraud engineering'. This was based on allegations of unlawfulness in the contractual procedure of the two companies meant to provide technological services to support the general elections, namely SINFIC (Industrial Information Systems and Consulting) and INDRA Systems (an information technology company). The issue was that despite the large sums involved (around 143 million euros), the two companies had been contracted without a public tender, in a fraudulent scheme operated by MPLA. SINFIC is a Portuguese company linked to Angolan businessmen, and INDRA is a Spanish company, also with shareholders close to the Angolan government. SINFIC was hired to prepare voters' rolls and the accreditation of party agents, and INDRA to supply voting material and technological solutions. The two companies also supplied materials for the 2012 elections, in which the opposition accused them of fraudulent dealings with the Angolan government. 
One important event that marked the preparation for the August polling was the Angolan government's refusal to allow the European Union (EU) to deploy an observer mission on the basis that EU requirements were unacceptable. The EU claimed that what they all needed was 'basic conditions, which are standard, access and impartiality for the operation of the mission' (ClubK 2017b, 31 July). In view of this, the EU decided to send only a five-expert mission to monitor the elections. A member of the EU Parliament said that the Angolan government did not invite the EU because 'they know that a European Union observation mission could see a lot of things that for sure and unfortunately would tarnish the credibility of the electoral process' (ClubK 2017b, 31 July).

The CNE decided not to implement either voting abroad or the special early vote, both of which are provided for in the Organic Law on General Elections (Law No. 36/11), allegedly due to the shortage of material and human, logistical and operational conditions. The law provides for early voting for those who are unable to leave their work stations on election day. This category can vote at the polling stations where they are registered five days before election day (ibid.). But the $\mathrm{CNE}$ argument was that early voting would promote the delocalisation of the vote, which is unlawful. Only party agents and polling stations staff would be able to vote outside their polling stations. The CNE also argued that the failure to conduct early voting was intended to avoid tarnishing the electoral process; but here the lack of clarity on the law or the unwillingness of the CNE is evident, excluding a considerable number of voters from the process in a repetition of the unresolved 2012 elections issues. The government issued a decree declaring election day a holiday to enable working voters to exercise their right. Logistical elements such as the availability of the postal vote, early vote, special vote, or voting abroad are important aspects used to assess the integrity of an election (Grömping \& Coma 2015).

The accreditation of party agents was involved in an uproar; on one side the CNE accused political parties of not sending their member lists to be accredited, which was immediately refuted by the political parties. They in turn accused the $\mathrm{CNE}$ of selective accreditation of party agents, and of giving preference to agents of the ruling party to the detriment of the opposition. Opposition political parties reminded the $\mathrm{CNE}$ that a possible exclusion from polling stations would be a clear violation of Article 118, section I, of the Organic Law on General Elections.

A few weeks before the polling CNE went public with a controversial announcement that after the polls were closed, ballot boxes would be transported to municipal centres where the counting would take place. This decision was regarded by most of the electoral stakeholders as contrary to the law that counting should be held at each polling station.

Voter registration is one of the issues that has negatively affected the integrity of elections on the continent (Grömping \& Coma 2015), and Angola 
was no exception. The voters' roll was also fraught with several incidents and allegations of deliberately relocating polling places; that is, citizens who at the time of their voter registration indicated where they would cast their vote, were later informed by the $\mathrm{CNE}$ that their names had been moved to other localities or even another province far away from their area of residence. The CNE refuted this claim, saying that the indication of the reference point given at the time of registration did not determine the polling station. The phenomenon of relocation seemed to be a repetition of the practice in the 2012 elections, which prevented a number of citizens from exercising their right to vote. There were also reports of voters who, because of technical problems, had not been issued with a voter's card when the roll was updated, and were thus unable to vote. In Angola the only acceptable identification document at the polls is the voter's card. An important recommendation for CNE Angola is to follow the example of the brother country, Mozambique, by introducing a regulation allowing voters who are duly registered but who do not have their registration cards on polling day to use other identity documents in order to vote. This option makes electoral processes far more inclusive.

Management of voter registration also dominated the pre-election phase. Article 107 (1) of the Constitution provides that the electoral administration must be conducted by an independent body. However, the MPLA used its majority in Parliament to pass Law 8/2015 transferring the responsibility of conducting voter registration to the executive, through the Ministry of Territory Administration (MAT), then led by MPLA vice-presidential candidate, Bornito de Sousa. The opposition obviously raised questions about the independence and transparency of this process, given that the MPLA played the role of player and referee at the same time. Furthermore, the management of voter registration data was also confused, with some names missing from the register.

During voter registration UNITA repeatedly accused MAT of manipulating voter registration data in its favour by selectively excluding areas known to be opposition strongholds and deliberately deleting some names from the voters' roll. The sharp decrease (by approximately three million) in the number of voters registered compared to those registered in the previous election heightened suspicions that the voters' roll lacked credibility, and automatically tarnished the credibility of the electoral process itself. MAT indicated two possible reasons for the missing three million: that they were deleted from the register because they had not visited voter registration centres to prove their existence, or because duplicate registrations had been deleted.

Figure 1 below shows the data of registered voters in elections from 1992 to 2017 , highlighting the decrease by $4.5 \%$ of the number of voters registered for the August 2017 elections. 


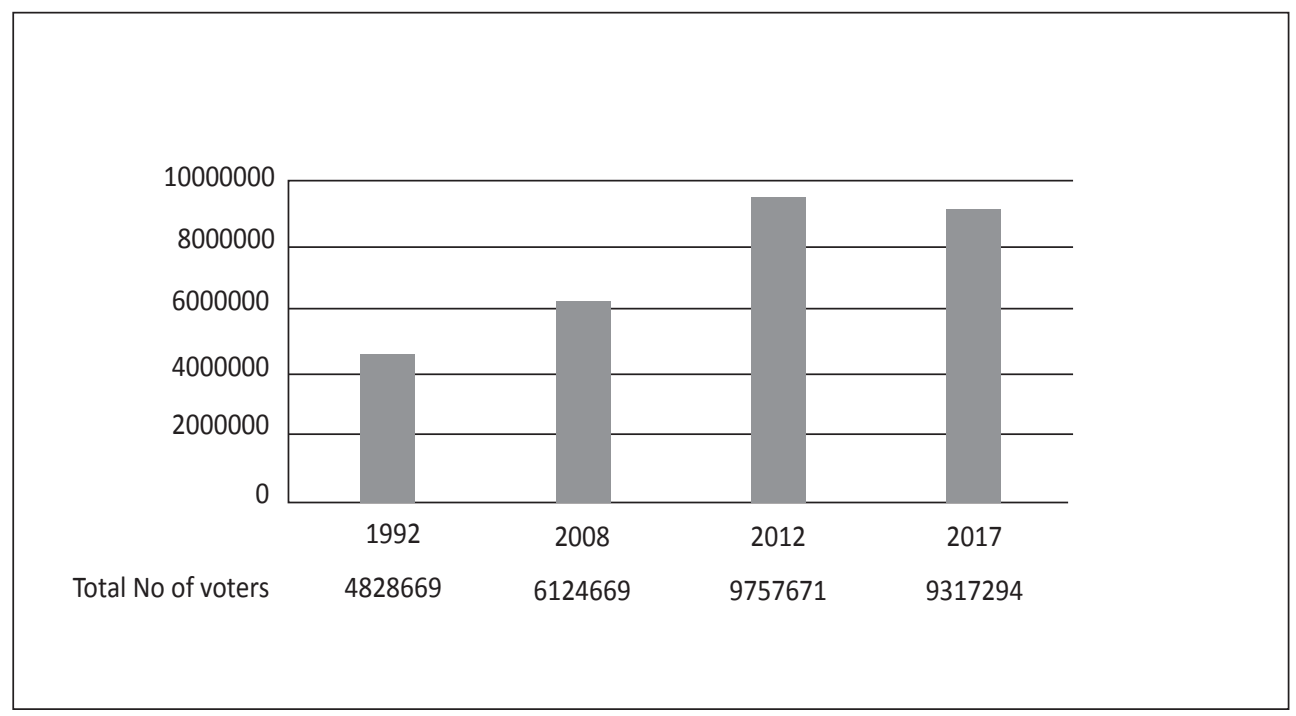

Source: Ministério da Justiça, 1995; IDD \& FKA, 2009; CNE, 2017

\section{Figure 1: Number of registered voters (1992 - 2017)}

The Angolan government guaranteed the timely disbursement of financial resources to the CNE for the preparation and conduct of the 2017 ballot, following the provisions of the Constitution.

\section{CANDIDATES}

Five political parties, together with a coalition of two parties, competed for the 220 seats in Parliament, making six contesters in total, namely the MPLA, UNITA, FNLA, PRS, APN and CASA-CE. APN was seen as a spoiler created by the MPLA government months before polling day to divide the opposition vote (Pearce et al. 2018) but it failed to win a single seat.

The MPLA list was headed by João Lourenco followed by Bornito de Sousa. UNITA once again bet on its historic leader, Isaías Samakuva. Lucas Ngonda was the preferred candidate of the historic but dying party, FNLA, after he had won a judicial battle and survived expulsion from the party. The PRS, an influential party in the rich diamond regions of Lundas, fielded Benedito Daniel. Quintino Moreira represented the new APN, and the CASA-CE coalition had former UNITA cadre Abel Chivukuvuku as its candidate. None of the lists were led by woman, nor were there any women candidates for the vice presidency, although women represented $54 \%$ of the national population. The representation of women in the National Assembly dropped down from 34.5\% in the 2012 elections to 26\% in 2017. 


\section{ELECTIONS CAMPAIGN}

The electoral campaign which ran from 23 July to 21 August was orderly, calm and tolerant, except for isolated incidents. Compared to previous campaigns, both candidates and citizens showed a responsible civic attitude with calls for massive participation in voting. The two former foes modified their usual belligerent stance and toned down their warmongering language.

The campaign was characterised by rallies, door-to-door contact, and the use of information technologies (mainly television, radio and social media). The opposition parties challenged Lourenço to a live television debate but the MPLA failed to respond. In comparison to the 2012 elections UNITA and CASA-CE ran an efficient campaign that attracted thousands of supporters to their rallies across the country (Pearce et al. 2018).

MPLA changed its campaign strategy from holding rallies in big stadiums with big luxury car parades in favour of door-to-door campaigning. Anecdotal evidence indicated that this was caused by concerns about the possible results with a new candidate. During the campaign, Lourenço's speech focused on combating corruption and restructuring the economy in order to end Angola's dependence on oil and diamond revenues (Africa Confidential 2017) and on diversifying the economy by using these oil and diamond revenues to create infrastructures that would uplift the economy.

The PRS party defended federalism and their candidate, Benedito Daniel, claimed that federalism would be the only way to end the blunt regional asymmetries and discrimination among Angolans. APN candidate Quintino Moreira's main campaign message was the hope for change, job creation and housing for low-income youth.

During the electoral campaign UNITA accused the MPLA and its candidate of returning to warmongering speeches in an attempt to foment hatred among the different population groups. In the words of UNITA's candidate, this was a ruling-party strategy to hide their failure to deliver during their 42 years in power. UNITA's allegation is not entirely false; Lourenço was quoted during the election campaign as stating that UNITA would be punished through the ballot box for the destruction of the country's industrial capacity during the war and the consequent unemployment among youth. But overall, the tone of this electoral campaigning was less bellicose than previously.

Media coverage is one of the most contentious issues of electoral processes worldwide (Grömping \& Coma 2015). To deal with this problem, contesting political parties in Angola are entitled, by law, to airtime in the public media with ten minutes on radio and five minutes on television per day for the duration of electoral canvassing. Contesting political parties had equitable access to airtime; 
however, this came immediately before the prime-time news bulletin which was dominated by biased coverage consisting mainly of reports about government investments in infrastructure. These had the effect of diminishing the opposition message.

In Angola the law also compels the public media to offer fair news coverage, an offer not respected by the public media. MPLA dominated both print and broadcast - and not only public media but also those in the private sector, because almost all the latter are owned by MPLA members, according to Pearce et al. (2018). Disrespect for the law was a repeat of the scenario that characterised the 2008 and 2012 elections.

A JIKU project monitored Angolan Public Television station TPA and private TV station Zimbo, as well as the public Rádio Nacional de Angola, Rádio Mais, Rádio Lobito, Rádio Morena and Rádio Huíla, between July 23 and August 20. This project concluded that almost $85 \%$ of the time spent by Angolan television and radio stations on election coverage favoured MPLA and the government. UNITA received only 4.2\% and CASA-CE 3.6\% (ClubK 2017c, 22 August).

This disproportionate access to public media was also of concern to Human Rights Watch, particularly because the Angolan public had limited alternatives to access information beyond the state media (ClubK 2017d, 8 August). The Angolan Journalists Union (SJA) also criticised both public media and part of the private media for favouring the MPLA in their coverage (ClubK 2017e, 10 August). Pearce et al. (2018, pp. 5-6) came to the same conclusion. This abuse of state media in particular was a reflection of the total disrespect for Article 64 of the Organic Law of Elections (Law no. 36/11, of December 21); however, despite a public outcry, this flagrant disregard went unpunished by the electoral monitoring authorities.

The campaign was also characterised by allegations of electoral corruption, although fewer than in previous elections. In August, UNITA filed a criminal lawsuit with the Attorney-General's Office against the MPLA candidate accusing him of improperly offering goods such as cars, motorcycles and televisions to voters, to traditional authorities and religious entities (ClubK, 2017f ,15 August). Again, this clearly disregards Article 193 of the Organic Law on General Elections, and again, the electoral oversight bodies took no action to enforce the law.

The incumbent's use of public resources, infrastructures and civil servants was also notorious. These included the use of Angolan Army (FAA) vehicles to transport MPLA supporters to rallies (ClubK 2017f) from one village or district to the other, often in inhuman conditions (ClubK 2017g, 15 August), to make MPLA rallies more visible and thereby influence public opinion. Public employees were coerced by their leaders to participate in MPLA rallies (ClubK 2017h, 17 August) contrary to Article 191 of the Organic Law on General Elections. As Pearce et al. (2018, p. 7) puts it 'it is not as a party that the MPLA went to the polls, but as a party-state, a logical outcome of Angolan post-war politics'. 
The misuse of the traditional authorities (sobas) resulted in an incident a few days before the elections. LTI (Logistics and Integrated Transport), the company responsible for distributing kits of electoral material, including ballot boxes and ballot papers, decided to deliver these materials to the residences of MPLAlinked sobas in several locations without any supervision, allegedly due to a lack of conditions to keep the ballot boxes safe in neutral places. This resulted in the loss of some material. In Catabola municipality a total of 3900 ballot papers disappeared. CNE confirmed the incident in a communiqué dated August 19 (ClubK 2017i, 22 August).

African elections are known for their poor performance in campaign finance, with an average score of 40, eight points below the global average (Grömping \& Coma, 2015). In Angola contesting parties are legally entitled to a state grant to finance their electoral campaign activities. In 2017 each party received a total of 250 million kwanzas (almost 1.3 million euros). However, the parties alleged that a late distribution of this funding compromised the organisation and preparation of their campaign activities.

One aspect worthy of note is that during the electoral campaign in Angola, the main focus was on the heads of the list to the detriment of the 220 candidates for the National Assembly. There is, however, an equal need for awareness about the identity of the MP candidates in different provincial constituencies; citizens need to know who they are and what they intend to do in Parliament to represent their constituencies.

\section{VOTING DAY AND ELECTION RESULTS MANAGEMENT}

The over nine million voters registered to vote were divided into 25873 polling stations aggregated into 12512 polling centres. Election day itself was generally calm. The national police and other security forces were on the ground and the army was combat-ready to ensure peace of mind during the vote. Recourse to the preventive function of security forces and the army may point, on the one hand, to some uncertainty on the part of the government in relation to the environment of the electoral process; but on the other hand, it could equally prove to be a form of intimidation used to influence voters' decisions.

Most polling stations opened on time ${ }^{1}$. However, some logistical problems occurred and there were reports of about 1310 voters who were unable to cast their votes in the provinces of Benguela, Lunda Norte and Moxico, allegedly due to technical problems. Cases of voters whose names could not be found in the voters'

1 The Law No. 36/11 determines that the voting starts at 7:00 a.m. (article 103, paragraph 1) and ends at 6:00 p.m. However, voters in the queue before 6:00 p.m. are allowed to vote (article 105, paragraph 2) until 7:30 p.m. 
rolls were also reported in some areas, and this too affected the integrity of the process. Several polling stations had no agents for some contesting parties. This may have been caused by the deficient accreditation of party agents by the CNE; but the contesting parties may also have lacked the human, material and financial capacity to deploy their own agents to cover all polling stations nationwide.

Trust in the work of an electoral management body is an important aspect determining the level of electoral integrity (Norris 2015, pp. 13-18). In the case of Angola voters and other stakeholders continued to have a low level of trust in the work of CNE, as a result of which opposition parties CASA-CE and UNITA undertook an independent, parallel vote count. On the day after the election MPLA claimed to have a qualified majority even before the announcement of the provisional results by the $\mathrm{CNE}$, as a result of which the opposition raised allegations of fraud (Pearce et al., 2018).

During the general elections of 23 August 2017, Angola was attended by 1200 national observers and 200 international observers. National observers were largely aggregated in the Angolan Electoral Observatory (OBEA) and the National Youth Council (CNJ). Notable former heads of state and government also attended, probably to bid farewell to their friend dos Santos. Figure 2 below summarises the election results.

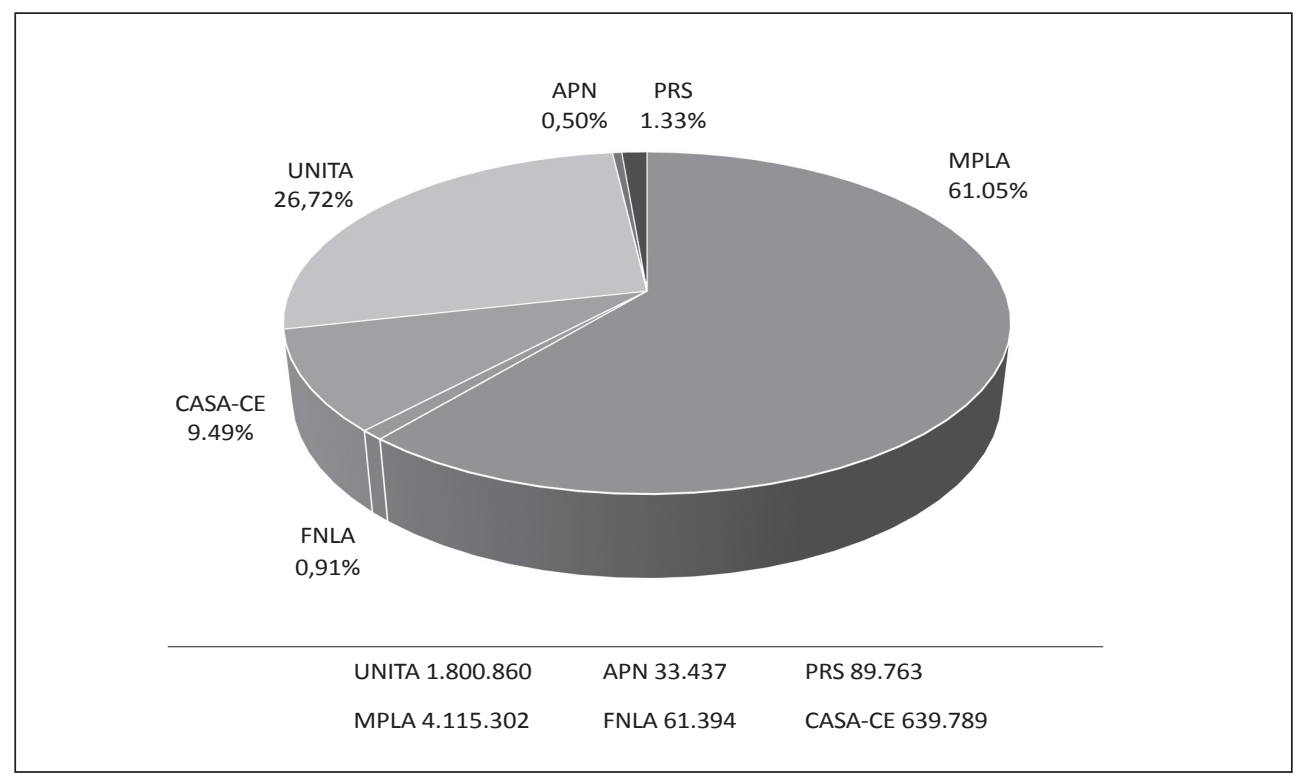

Source: CNE, 2017

Figure 2: 2017 Election Results 


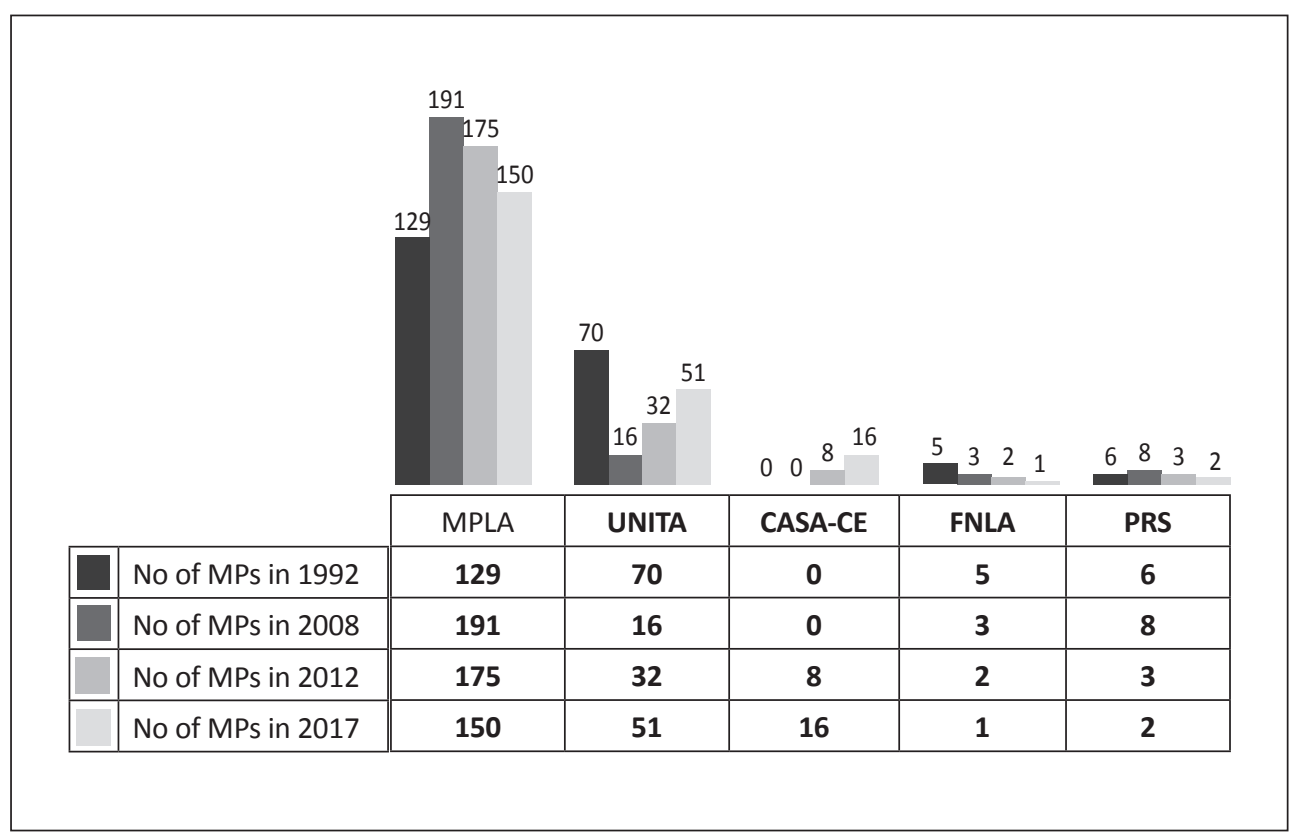

Source: Ministério da Justiça 1995; IDD \& FKA 2009; CNE 2017.

Figure 3: Number of elected MPs per political party (1992 - 2017)

MPLA was the biggest loser in the 2017 general elections; in the opposite direction CASA-CE and UNITA increased their seats. The increase by the two parties can have a dual interpretation; firstly, the vote for these two may be punishment for the MPLA's poor governance. This had been marked by endemic corruption and the social exclusion of most of the population who have been deprived of basic sanitation and health services, quality education, employment and safety. Alternatively, the vote for these two may indicate a reward for their good performance in the Angolan Parliament, without minimising their sound proposals during the electoral campaign.

The opposition rejected the results on the grounds that the elections had been conducted in an unconstitutional manner for the following reasons:

- most of the results in almost all provinces were processed illegally by people not authorised to do so

- some ballot boxes had disappeared and new ballot boxes appeared

- the results were announced without the requisite results sheets from some provincial electoral commissions, and this may in turn have revealed that the national results were incorrect and fraudulent. 
All these allegations were rejected by the CNE (Pearce et al. 2018). By finding the final results fraudulent, UNITA and CASA-CE decided not to take their seats in the National Assembly in protest against what they considered illegal results. They took the protest to the Constitutional Court, but all allegations were rejected. Later the two parties decided to allow their representatives to take their seats in Parliament, a decision that was not welcomed by the public who considered them weak.

\section{ANALYSING THE MPLA PERFORMANCE}

MPLA lost over $10 \%$ of its electorate compared to the 2012 elections when dos Santos stood as their candidate (see Figure 4 below); a clear indication that dos Santos was not the only problem. However, some commentators are of the view that if dos Santos had stood again MPLA results would have been even worse. Figure 4 below reveals a sharp decrease in support for the MPLA immediately after 2008.

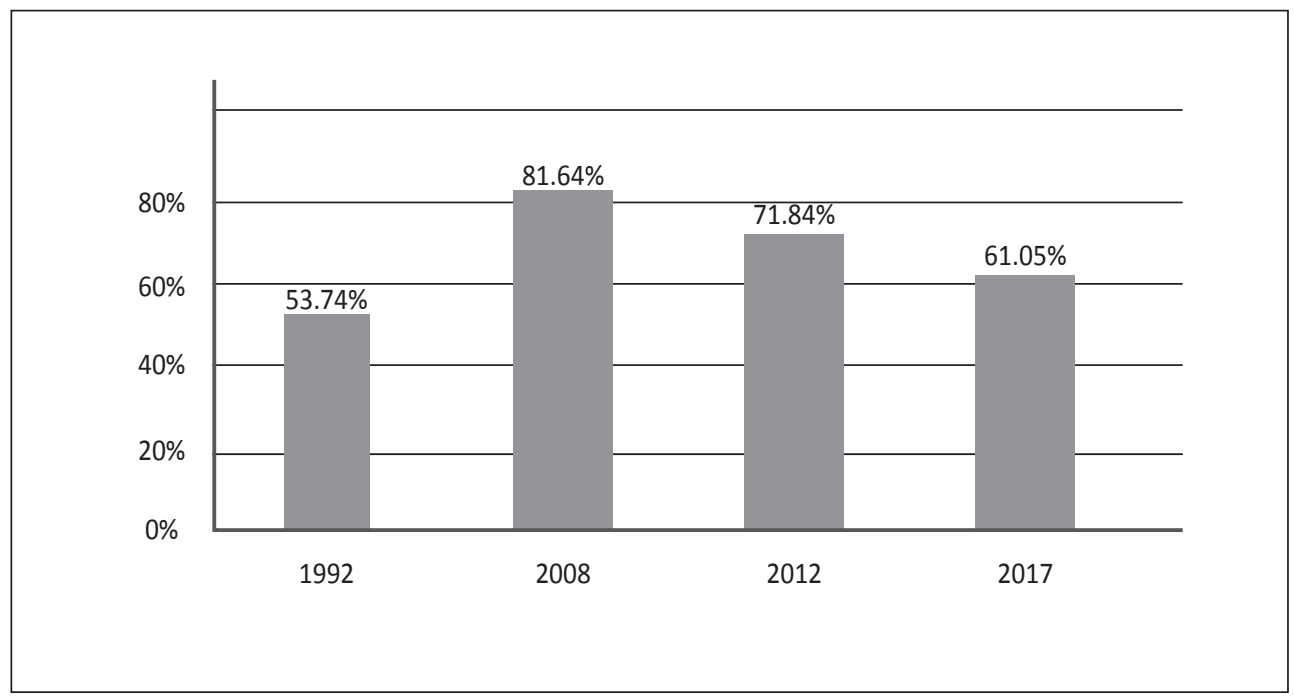

Source: Ministério da Justiça 1995; IDD \& FKA 2009; CNE 2017

Figure 4: Election results for MPLA since 1992

The sharp increase of the MPLA vote share from the first elections in 1992 to the second elections in 2008 may be linked to substantial investment in the reconstruction of the country, propelled by an economic performance driven by the high oil price. Furthermore, dos Santos may have been largely credited with 
having ended the long and horrendous civil war after the death of Jonas Savimbi, the man blamed for all the country's ills. Between 2008 and the 2012 elections MPLA lost $9.8 \%$ of electoral support, marking the beginning of the waning of its popularity.

In 2017 MPLA lost a further $10.79 \%$ even with a new candidate. The immediate result was that the position of Lourenço was negatively affected by problems inherited from his predecessor, and also by the poor economic performance and recent hardships the country had experienced. Lourenço was not well known by the voters and this may have had an impact on party preference, particularly because of the short interval between announcing his candidacy and the election. In normal circumstances the entrance of Lourenço into the electoral race would gain some sympathy for the MPLA from the electorate; however, uncertainty regarding the continuity or discontinuity of his predecessor's governance model may have had a negative impact on his candidacy.

Another important mark of the 2017 elections is the slight drop in abstentions to $23.4 \%$ compared to $37.2 \%$ in the previous elections. The turnout was slightly higher in 2017 which may be associated with a number of factors: firstly, MAT indicated that 2.5 million registered voters were new or had registered for the first time. These may have been keen to exercise their rights for the first time, adding to the pool of previous traditional voters. Secondly, the hope for a possible change after the withdrawal of dos Santos and the expectations raised by the pre-election environment drove voters to turn out in increased numbers to the polling stations, including those who had not shown any interest in previous elections. As one of the social activists remarked 'this time I will vote... [because]... the context is different, almost everything is different' (ClubK 2017J, 15 August). Lastly, the good performance of CASA-CE and UNITA referred to earlier may have attracted many voters, including disgruntled MPLA supporters, to turn up in their numbers.

In African elections the vote count and the period immediately following the results announcement is consistently rated as the time in the election cycle most likely to experience possible conflict. In most cases the opposition challenges the results using legal channels or by organising massive demonstrations. If not handled properly this protest can end in violence (Grömping \& Coma 2015), and Angola was no exception, as the period following the polling and release of the final electoral results was one of political tension. Aware of these dangers, the government deployed troops, intensified intelligence activities and increased police presence in the known hotspots around the country. In Viana municipality, for example, the Sovismo complex where UNITA's General Secretariat operates saw an increase in the number of security forces. The hope of change was replaced by a climate of fear.

Youth groups planned a protest march in Luanda against the alleged manipulation of electoral results, but this march was aborted due to the heavy presence 
of security forces. However, the post-electoral phase did not turn violent because the opposition parties called for calm, peace and adherence to the legal framework of the country, a call that may have contributed significantly to post-election stability. So it would seem that Angolans have learned their lesson from 1992, when war erupted following Savimbi's refusal to accept the results.

\section{POLITICS AFTER DOS SANTOS}

The 2017 elections constitute the first time that Angola has experienced a change of leadership. There are several uncertainties about how the new president and the MPLA will handle this transition, in particular whether he will contest the economic hegemony of dos Santos, and what kind of political change he is likely to institute.

The reality is that Lourenço has the difficult task of handling the many and various challenges facing the country. These range from the liquidity crisis to the popular dissatisfaction of Angolans because of the degradation of their living conditions, and the political pressure resulting from the change of party leadership. He is likely to face some kind of resistance from the heirs to dos Santos's economic hegemony and at the same time needs to mark his own terrain and gain acceptance of his position in power (Roque 2018).

The implication is that dos Santos will continue to command the MPLA and Lourenço will simply be the president of the republic, a situation where it is known that the party is more powerful than the government. The general belief is that Lourenço is likely to alter some aspects of party politics with discretion, but the truth is that until dos Santos resigns as party leader Lourenço may have difficulty creating his own space and forging his own way.

Another question is how Lourenço will deal the economic power of dos Santos and his allies. Some of the actions Lourenço took immediately after his inauguration included the removal of dos Santos loyalists in most of the stateowned companies such as Sonangol and the Sovereign Fund of Angola, two important companies in the hands of dos Santos children. Lourenço also passed decrees dismantling the exclusive ownership of businesses by certain families, including that of the former presidential family. These businesses included TPA II and Brumangol. The government also initiated investigations into some suspicious financial transactions carried out in the previous management of Sonangol, the Sovereign Fund of Angola and the National Bank of Angola.

Although the country was plunged into crisis, dos Santos decided to step down without drawing up a reform plan for the country (Roque 2018). Lourenço inherited these economic problems, in particular the excessive dependence on oil revenues and external debt service. To reverse this situation Lourenço will have to adopt the necessary changes for a diversification of the economy. 
Beyond the shadow of dos Santos and Angola's economic problems, Lourenço inherits a state marred by social disfunction brought on by popular discontent, especially among the youth who agitate for change. This situation offers two options to Lourenço. The first would be to institute greater momentum to unlock social investments, blocked by the interests of dos Santos to protect his business interests. The second would be to make a paradigm shift and persuade his comrades to abandon the discourse portraying MPLA as the historic liberator, saviour, and owner of Angola. Instead, to give greater focus to a discourse that would attract a new generation removed from the MPLA's historic role of liberating Angola from colonialism.

Lourenço has started carrying out visible changes that are already finding favour with many citizens. These include the reduction of military apparatus and fleets in his convoys, closing the political propaganda office in the presidency, and replacing the governor of the national bank; but more actions are needed. Lourenço's great advantage is that he is seen as a tolerant leader. This quality can be of considerable value in calming popular opposition to the MPLA and its government and in improving their levels of acceptance and governance. A significant indication of this political tolerance was demonstrated by his meeting with the president of UNITA to discuss how to undo the partisan nature of the state, a move that was welcomed by Angolans.

In a move that has been widely praised at home and abroad, Lourenço has adopted a law to repatriate any Angolan money that had been illegally exported. Once fulfilled, this measure can give the economy a boost and act as a catalyst for development. The repatriated capital would be used for investment in Angola and contribute significantly to job creation, increased welfare and to reduce social tensions. So far, the government has been able to recover 500 million American dollars illegally transferred to Credit Suisse Bank of London by the former governor of the National Bank of Angola at the request of the Angolan government. The Mauritian government has also frozen about 206 million American dollars belonging to Jean-Claude Bastos de Morais, a business partner of Filomeno dos Santos, son of dos Santos.

Regardless of any effort Lourenço may undertake, past problems will continue to haunt Angola and will take some time to remedy. One concern is regarding the general state budget as the new government continues to make the same mistakes as its predecessor. These are particularly manifest in the overbudgeting of state security services and external debt service to the detriment of key sectors such as health, education and agriculture.

In Angola the contribution of the opposition parties towards political change remains minimal. This is not to ignore the good work which resulted in positive election results, as indicated by UNITA and CASA-CE. The major factor for the 
continued weakening of the opposition is their limited access to operational funds. With MPLA holding economic and political control, opposition parties will continue to depend on MPLA financially and even politically. Furthermore, fragmentation will make them vulnerable to enticements by the ruling party and limit their ability to act in unison against the MPLA's overwhelming power (Pearce et al. 2018).

\section{CONCLUSION}

The general elections of 2017 raised the expectations of an end to the MPLA's hegemony through the ballot and consequent introduction of political and economic changes in the country. However, the final results were a disappointment because they showed that even without dos Santos, the MPLA would continue to dominate the political dynamics of the country.

The departure of dos Santos and the installation of a new government is not enough to end Angola's problems, especially the corruption, patronage and abusive use of state assets. Lourenço's allies, most of whom did not enjoy the benefits of dos Santos's patronage, will also want their share - 'it is their turn eat'. This situation will put Lourenço under huge pressure to fight the ills of the past and at the same time deal with a repetition of the same mistakes in his entourage and on his watch.

The electoral campaign of 2017 doubtless deserves some recognition for its improvements compared to previous elections. This is especially with regard to the peaceful environment and political tolerance that prevailed, the active participation of various spheres of society, better logistics by the CNE, and the political maturity of both candidates and voters. However, there are still some problems that have tarnished the country's electoral integrity; given Angola's past experience in electoral processes, these would seem to be more than mere operational errors.

The MPLA experienced a general decline in its electoral performance, even in regions considered its stronghold such as Luanda province. This decline has several interpretations; first, the results reveal a general fatigue and dissatisfaction on the part of the electorate towards MPLA governance. In other words, the problem of Angolans is not only dos Santos but the liberation party as a whole. Second, the decline may have been caused by the opposition's success in mobilising more supporters, especially young people born after independence and after the civil war, who do not venerate the MPLA and its claim of being the nation's liberator and therefore having the right to govern Angola.

This seems to be following the trends of liberationist parties throughout the Southern African Development Community (SADC) that tend to lose ground in 
post-independence elections. Fortunately, there are already significant indications that Santos may cede the party's command to Lourenço as the MPLA plans to have an extraordinary conference in September to elect a new chair. This may end the conflicting centres of power, but it is not yet known what level of influence dos Santos and his allies will continue to field in the party. This is particularly true of those wielding power in the economy at both central level and in the provinces. They are more likely to block any reform efforts Lourenço may wish to introduce, unless Lourenço and his government resort to an authoritarian solution as their predecessor has always done.

\section{- REFERENCES}

Africa-Confidential 2017, <https://www.africa-confidential.com/article/id/12084/ Dos_Santos_Inc._under_threat>

Amundsen, I \& Weimer, M 2008, 'Opposition Parties and the 2008 Parliamentary Elections in Angola', CMI Working Paper 9, Bergen, 2008, p. 60.

Angola. Ministério da Justiça 1995, Angola: livro branco sobre O processo de paz, vol. 1, 31 de Maio de 1991-31 de Maio de 1993, Ministério da Justiça, Luanda.

Anstee, JM 1997, Órfão da guerra fria: radiografia do colapso do processo de paz angolano, 1992/93 Campo das Letras, Porto.

António, ND 2015, Transição pela transação: uma análise da democratização em Angola, PoloBooks, Rio de Janeiro.

Blaauw, L 2014, 'Reinforcing Authoritarian: Rule Electoral Politics in Angola', Journal of African Elections, vol. 13, no. 2.

CEIC - Centro De Estudos E Investigações Científicas 2012, Relatório Social de Angola 2012, Nova Lito, Luanda.

ClubK 2017a, <http://www.club-k.net/index.php?option=com_ content\&view $=$ article\&id $=28991$ :

ClubK 2017b, <http://club-k.net/ clubknet/index.php?option=com_ content\&view $=$ article\&id $=28783>$

ClubK 2017c, <http://www.club-k.net/index.php?option=com_ content\&view $=$ article\&id $=29106>$

ClubK 2017 d, http://www.club-k.net/ clubknet/index.php?option=com_ content\&view $=$ article\&id $=28901$

ClubK 2017e, $<$ http://www.club-k.net/ clubknet/index.php?option=com_ content\&view $=$ article\&id $=28917>$

ClubK 2017f, <http://www.club-k.net/index.php?option=com content\&view $=$ article\&id $=29004>$

ClubK 2017g, <http://www.club-k.net/index.php?option=com_ content\&view=article\&id=29026> 
ClubK 2017h, <http://www.club-k.net/index.php?option=com_ content\&view $=$ article\&id $=29038>$

ClubK 2017i, <http://www.club-k.net/index.php?option=com_ content\&view $=$ article\&id $=29123>$

ClubK 2017j, <http://www.club-k.net/index.php?option=com_ content\&view $=$ article\&id $=29007>$

CNE, 2017, Compêndio de legislação eleitoral, Imprensa Nacional, Luanda.

Dahl, R 1998, On democracy, Yale University Press, New Haven \& London .

Dahl, R 1997, Poliarquia: participação e oposição, Edusp, São Paulo.

Freedom House 2018, Angola, <https://freedomhouse.org/report/freedomworld/2018/angola>

Grömping, M \& Coma, FM 2015, 'Electoral Integrity in Africa', Electoral Integrity Project, vol 22.

Human Rights Watch 2012, Eleições em Angola. Ataques ao Média, Direitos de Expressão e Reunião, Human Rights Watch, USA.

Instituto De Desenvolvimento E Democracia \& Fundação Konrad Adenauer (IDD \& FKA) 2009, Angola, livro branco sobre as eleições de 2008: contributo para a democratização dos processos eleitorais em Angola, IDD \& FKA, Luanda/Namíbia. Mathenjwa, MJ 2017, 'Election Deposit and Democracy in Developing Countries: A Comparative Overview in Selected Southern African Development Community Countries', Journal of African Elections, vol. 16 no. 1.

Messiant, C 1994, 'Le retour à la guerre ou l'inavouable faillité d'une intervention internationale', in Áfrique politique, Karthala, Paris.

Messiant, C 2008, 'Transição para o multipartidarismo sem transição para a democracia', in O processo de transição para o multipartidarismo em Angola, Firmamento \& Livraria Nobel, Luanda e Lisboa.

Messiant, C 2008, L'Angola postcolonial: guerre et paix sans démocratisation, Karthala Éditions, Paris.

Pearce J et al. 2018, Briefing Angola's Elections and The Politics of Presidential Succession, Oxford University Press on behalf of Royal African Society, Oxford.

Portugal, Artigo 102॰, n.22, da Lei n.॰ 36/11.

Roque, PC 2017, 'Reform or unravel? Prospects for Angola's transition', Institute for Security Studies, no. 824 May.

Schubert, J 2013, 'Democratização e consolidação do poder político do pós-guerra em Angola', Relações Internacionais, March, pp. 79-98.

Tali, J-M M 1997, 'L'interminable transition angolaise et les multiples dangers de l'incertitude politique', Lusotopie, pp. 87-103.

Transparency International 2017, <https://www.transparency.org/news/feature/ corruption_perceptions_index_2017?gclid=EAIaIQobChMIv8PAtOys2wIV CyjTCh2P7wcLEAAYASAAEgKPvPD_BwE> 
Vidal, N 2008, 'Multipartidarismo em Angola', in: O processo de transição para o multipartidarismo em Angola, Firmamento \& Livraria Nobel, Lisbon and Luanda. 